Ethos: Jurnal Penelitian dan Pengabdian Masyarakat, Vol 9 No.2, Juni 2021: 161-168

\title{
Pemeriksaan dan Pendidikan Pencegahan Pedikulosis Kapitis Pada Santri Pesantren Jabal Nur Kecamatan Kandis, Kabupaten Siak, Provinsi Riau
}

\author{
${ }^{1}$ Esy Maryanti, ${ }^{2}$ Enny Lestari, ${ }^{3}$ Afrinaldi, ${ }^{4}$ Fadly Mulia, ${ }^{5}$ Mislindawati \\ 1,2,3,4,5 Fakultas Kedokteran Universitas Riau, Jl. Diponegoro No.1 Pekanbaru, Riau, Indonesia \\ email: 'esy.maryanti@gmail.com, 2ennylestari80@gmail.com,3afrinaldialdi2000@gmail.com, \\ fadlymulia18@gmail.com, ${ }^{5}$ mislindawati@gmail.com
}

\begin{abstract}
Pediculosis capitis is an infectious parasitic disease which is still a health problem, especially for people who live together in groups. Pesantren is a place where a group of students study and live together. They carry out daily activities together, from sleeping, eating, studying and playing. This student activity is one of the risk factor of contracting a parasite infestation. This activity aims to determine the incidence of pediculosis capitis, conduct health education, namely counseling about the eradication of the disease and providing treatment to students who are infested with Pediculus humanus capitis. This activity was carried out at the Pesantren/Islamic boarding School in Kandis District, Siak Regency. The target audience was the sanawiah student were 70 students. There were 36(51,4\%) students with pediculosis capitis. Students who had been diagnosed were given permethrin $1 \%$ and serit comb, after given treatment and education to prevent the disease, it is hoped that the students will be ableto apply the knowledgegained to eradicate the disease.
\end{abstract}

Keywords: boarding school, pediculosis capitis, Pediculus humanus capitis, students

\begin{abstract}
Abstrak. Pedikulosis kapitis adalah penyakit parasitik menular yang sampai sekarang merupakan masalah kesehatan terutama pada orang yang tinggal bersama secara berkelompok. Pesantren merupakan tempat sekelompok santri belajar dan tinggal bersama. Mereka melakukan kegiatan sehari-hari bersama, mulai dari tidur, makan, belajar, dan bermain. Kegiatan bersama santri ini merupakan salah satu risiko mudahnya tertular infestasi Pediculus humanus capitis. Kegiatan pengabdian kepada masyarakat ini bertujuan untuk mengetahui kejadian pedikulosis kapitis, melakukan pendidikan kesehatan, yaitu penyuluhan tentang pemberantasan penyakit tersebut, dan memberikan pengobatan pada santri yang terinfestasi pedikulosis kapitis. Kegiatan ini dilaksanakan di Pondok Pesantren di Kecamatan Kandis, Kabupaten Siak. Khalayak sasaran adalah santri sanawiah yang berjumlah 70 orang. Terdapat 36 (51,4\%) santri terkena pedikulosis kapitis. Santri yang sudah didiagnosis tersebut langsung diberikan permethrin 1\% dan sisir serit. Setelah diberikan pengobatan dan pendidikan pencegahan penyakit tersebut diharapkan santri dapat mempraktikkan pengetahuan yang didapat dalam rangka memberantas infestasi Pediculus humanus capitis.
\end{abstract}

Kata Kunci: santri, pedikulosis kapitis, Pediculus humanus capitis, pesantren

\section{Pendahuluan}

Penyakit parasitik masih merupakan masalah kesehatan di Indonesia (Sardjono, 2008). Di antara penyakit parasitik yang masih sering terjadi dan terabaikan adalah infestasi pedikulosis kapitis. (Feldmeier et al., 2009). Pedikulosis kapitis merupakan penyakit yang disebabkan oleh kutu 
kepala atau Pediculus humanus capitis. Penyakit ini merupakan masalah kesehatan di masyarakat. Infestasi parasit ini sering terjadi pada anak terutama umur 5-13 tahun. Penyakit kutu kepala ini dapat menyebabkan masalah sosial pada anak, perasaan tidak nyaman dan malu, kecemasan orang tua, dan penyebab tidak hadirnya anak di sekolah. Penyakit ini mudah sekali menular dan membutuhkan perhatian khusus untuk pemberantasannya. Penyakit tersebut tidak bersifat fatal, tetapi infestasi parasit ini dapat bersifat kronis. (Nutanson et al., 2008; Soedarto, 2011).

Pedikulosis kapitis atau penyakit kutu rambut/kepala mempunyai gejala klinis berupa gatal di kepala yang dapat mengganggu aktivitas sehari-hari (Menaldi et al, 2015; Natadisastra et al, 2009). Kejadian infestasi parasit ini masih tinggi terutama pada orang yang tinggal bersama secara berkelompok (Gharsan et al, 2016). Oleh karena itu, pedikulosis kapitis sering ditemukan pada anak-anak yang tinggal di panti asuhan atau asrama, seperti pesantren yang mempunyai jumlah anak didik atau santri yang banyak. (Sungkar et al., 2019). Beberapa penelitian menunjukkan angka kejadian infestasi kutu kepala di pondok pesantren cukup tinggi. Penelitian pada santri Pondok Pesantren Miftahul Ulum, Kabupaten Jember tahun 2018 didapatkan sebanyak $74,6 \%$ santri positif terkena pedikulosis kapitis (Lukman et al., 2018), begitu juga dengan penelitian di pesantren Desa Pamijahan, Kabupaten Bogor didapatkan angka kejadian infestasi kutu kepala pada santri perempuan sebesar $88,4 \%$. (Sungkar et al., 2019).

Menurut Undang-Undang Republik Indonesia No. 18 Tahun 2018, pondok pesantren adalah lembaga yang berbasis masyarakat didirikan oleh perorangan/yayasan/masyarakat yang menanamkan keimanan dan ketakwaan kepada Allah Swt.; menyemaikan akhlak mulia; serta memegang teguh ajaran Islam. Peserta didik atau yang disebut juga sebagai santri tinggal atau bermukim di pondok atau asrama selama proses pendidikan (UU No. 18 Tahun 2018). Selama di pesantren, santri tinggal bersama dan melakukan aktivitas secara bersama. Pesantren merupakan tempat yang strategis untuk melakukan pengabdian masyarakat. Berbagai kegiatan dapat dilakukan seperti penyediaan air siap minum bagi santri (Nasir et al., 2016) dan penyediaan sumber listrik alternatif (Kurniawan et al., 2019). Pada bidang kesehatan, banyak hal yang dapat dilakukan, salah satunya adalah pemeriksaan penyakit parasitik menular, yaitu pedikulosis kapitis.

Kegiatan pengabdian kepada masyarakat ini dilakukan di pondok pesantren yang berada di Kecamatan Kandis, Kabupaten Siak. Tingkat pendidikan yang ada di pesantren ini mulai dari sekolah menengah pertama/sanawiah dan sekolah menengah atas/aliyah. Pesantren ini didirikan pada tahun 2001 dan saat ini memiliki banyak santri. Lingkungan pondok sangat berisiko untuk terjangkitnya penyakit parasitik. Oleh karena itu, perlu dilakukan pemeriksaan penyakit pedikulosis kapitis supaya dapat dilakukan upaya pencegahan dan pemberantasan penyakit parasitik ini pada anak-anak santri sanawiah. Kegiatan dalam rangka pengabdian kepada masyarakat perlu dilaksanakan di pondok pesantren tersebut. Kegiatan ini bertujuan untuk menentukan angka kejadian infestasi Pediculus humanus capitis, mengetahui faktor risiko penyakit tersebut, dan melakukan pendidikan kesehatan berupa penyuluhan pencegahan dan penatalaksanaan pedikulosis kapitis pada santri yang terinfestasi. 


\section{Metode Ilmiah}

Kegiatan pengabdian kepada masyarakat ini dilaksanakan selama satu minggu pada bulan Oktober 2020. Beberapa tahap yang dilakukan pada kegiatan pengabdian ini adalah survei tempat, yaitu di Pondok Pesantren Kecamatan Kandis, Kabupaten Siak; mengurus perizinan; melakukan pemeriksan fisik rambut dan kepala pada santri sanawiah; mengisi lembar formulir identitas dan observasi tentang faktor risiko pedikulosis kapitis serta pendidikan kesehatan kepada santri, musyrif, dan musyrifah berupa penyuluhan dalam rangka untuk pencegahan dan pemberantasan penyakit pedikulosis kapitis. Santri juga diberikan sisir serit, satu orang satu sisir dan pengobatan berupa pemberian lotio permethrin $1 \%$ pada santri yang terinfestasi dengan kutu kepala.

Pendekatan yang dilakukan adalah mulai dari penjelasan kegiatan pengabdian, kemudian melakukan inform consent kepada santri sanawiah (didampingi oleh musyrif dan musyrifahnya) yang merupakan khalayak sasaran utama pada pengabdian ini yang berjumlah 70 orang santri sanawiah kelas 1 dan 2. Setelah itu, dilakukan pemeriksaan fisik pada rambut dan kepala untuk mengidentifikasi Pediculus humanus capitis. Pemeriksaan dilakukan sesuai dengan protokol kesehatan di masa pandemi corona virus disease (Covid19), yaitu dengan memakai masker, face shield, dan sarung tangan.

Pengisian lembar identitas dan observasi faktor risiko pedikulosis kapitis dilaksanakan melalui wawancara terpimpin dengan santri. Kegiatan pendidikan kesehatan berupa penyuluhan tentang pedikulosis kapitis yang dilakukan oleh empat orang tim dari Fakultas Kedokteran, Universitas Riau (1 orang dokter dan 3 orang dokter muda) dengan metode interaktif perorangan dengan menggunakan bahasa yang mudah dimengerti oleh santri. Penyuluhan berisi tentang pengertian, penyebab, penyebaran penyakit, manifestasi klinis, patofisiologi, diagnosis, penatalaksanaan, prognosis, pencegahan, dan komplikasi dari pedikulosis kapitis.

Alat ukur ketercapaian kegiatan pengabdian kepada masyarakat ini adalah diketahuinya angka kejadian pedikulosis kapitis pada santri dan faktor risikonya; terlaksananya kegiatan pendidikan kesehatan berupa penyuluhan tentang pencegahan dan pemberantasan pedikulosis kapitis; pemberian sisir serit dan obat lotion permethrin $1 \%$ pada santri yang terinfestasi dengan Pediculus humanus capitis.

\section{Hasil dan Pembahasan}

Pesantren adalah sebuah asrama pendidikan yang peserta didik atau santrinya tinggal bersama dan belajar dibawah bimbingan kiai/tuan guru dan pengelola pesantren. Pondok pesantren di Kecamatan Kandis, Kabupaten Siak merupakan pesantren yang didirikan untuk mempelajari ilmu agama dan umum bagi santri tingkat sanawiah dan aliah. Berdasarkan obervasi di pesantren tersebut, kehidupan pesantren merupakan kehidupan yang terjadwal mulai dari bangun tidur sampai tidur lagi. Umumnya kegiatan yang dilakukan oleh santri dilakukan secara bersama, seperti belajar, makan, tidur, dan bermain/istirahat bersama. Kegiatan bersama ini merupakan salah satu faktor risiko untuk terinfestasi oleh parasit, seperti pedikulosis kapitis.

Kegiatan pengabdian kepada masyarakat ini telah berhasil melakukan pemeriksaan rambut/kepala santri untuk mengetahui penyakit pedikulosis kapitis di Pondok Pesantren, Kecamatan Kandis, Kabupaten Siak yang berjumlah 
70 orang. Hasil pemeriksaan dapat dilihat pada Tabel 1 berikut.

Tabel 1

Hasil Pemeriksaan Kutu Rambut/Kepala

\begin{tabular}{|c|c|c|}
\hline \multirow[t]{2}{*}{ Variabel } & \multicolumn{2}{|c|}{$\begin{array}{c}\text { Infestasi } \\
\text { P.h. capitis }\end{array}$} \\
\hline & Positif & Negatif \\
\hline \multicolumn{3}{|l|}{ Jenis Kelamin } \\
\hline - Laki-Laki & 0 & 31 \\
\hline - Perempuan & 36 & 3 \\
\hline \multicolumn{3}{|l|}{ Usia } \\
\hline - $\quad 11$ tahun & 2 & 1 \\
\hline - 12 tahun & 23 & 7 \\
\hline - 13 tahun & 11 & 14 \\
\hline - $\quad \geq 14$ tahun & 0 & 12 \\
\hline
\end{tabular}

Berdasarkan hasil pemeriksaan pada tabel 1 didapatkan sebanyak 36 santri $(51,4 \%)$ terinfestasi Pediculus humanus capitis. Sebagian besar santri perempuan, yaitu 92,3\% (36 dari 39 santriwati) positif pedikulosois kapitis.

Infestasi Pediculus humanus capitis ini sering terjadi pada anak usia sekolah dan penularannya sangat mudah pada sekelompok orang yang tinggal bersama yang tidak terlalu memperhatikan kebersihan pribadi serta lingkungan tempat tinggal, seperti di panti asuhan, pesantren atau asrama (Sungkar et al., 2019; Nutanson et al., 2008).

Tingginya angka kejadian infestasi Pediculus humanus capitis pada santri di pesantren ini mungkin disebabkan anak perempuan berambut panjang dan tidak teratur mencuci rambut. Berdasarkan wawancara dengan santri perempuan, mereka mencuci rambut lebih kurang $1-2$ kali seminggu, tetapi tidak sempat untuk mengeringkan rambut,. Umumnya, rambut santri perempuan panjang dan mereka menggulung dan mengikat rambutnya dalam keadaan basah serta langsung mengenakan jilbab. Rambut yang basah dan keadaan kepala yang lembab ditambah lagi bercampur keringat merupakan kondisi yang menguntungkan bagi hidup Pediculus humanus capitis. Alasan santri tidak sempat mengeringkan rambut setelah dicuci karena kurangnya waktu dan kegiatan lain sudah menunggu untuk dilaksanakan. Hal ini terjadi pada santri kelas 7 karena santri ini masih baru di lingkungan pesantren sehingga belum sepenuhnya beradaptasi dengan kehidupan dan jadwal di asrama.

Selain hal tersebut, berdasarkan beberapa penelitian, infestasi Pediculus humanus capitis lebih banyak terjadi pada anak perempuan dibanding anak laki-laki. Hal ini disebabkan umumnya anak perempuan mempunyai rambut yang panjang dan mempunyai kontak yang erat dengan sesama temannya sehingga menyebabkan penularan lebih mudah terjadi (Lye et al., 2017). Berdasarkan wawancara pada santri perempuan, mereka sering bertukar tempat tidur atau tidur di tempat tidur temannya sehingga menggunakan bantal secara bersama yang memudahkan penularan parasit tersebut. Selain itu, kebiasaan santri kadang menggunakan peralatan atau asesoris rambut bersama, seperti ikat rambut dan pinjam-meminjam sisir rambut, bahkan pinjam-meminjam jilbab.

Pada penelitian yang dilakukan di Pondok Pesantren Miftahul Jember didapatkan sebanyak $74,6 \%$ santriwati positif infestasi Pediculus humanus capitis. Pada penelitian tersebut juga didapatkan hubungan yang bermakna antara kejadian pedikulosis kapitis dan faktor risiko, seperti penggunaan sisir dan aksesoris rambut bersama, frekuensi cuci rambut, panjang lambut, dan jenis rambut. (Lukman et al., 2018)

Pada pemeriksaan kutu kepala ini, seperti yang terlihat pada gambar 1, umur santri yang positif pedikulosis kapitis adalah 11 - 13 tahun, yaitu santri kelas 1 dan 2 sanawiah. Berdasarkan penelitian, anak yang sering terinfestasi kutu kepala adalah anak yang berumur 5 - 13 tahun karena 
pada umur ini adalah umur bermain dan mempunyai kontak yang erat dengan temannya (Nutanson et al.,2008; Lye et al., 2017).

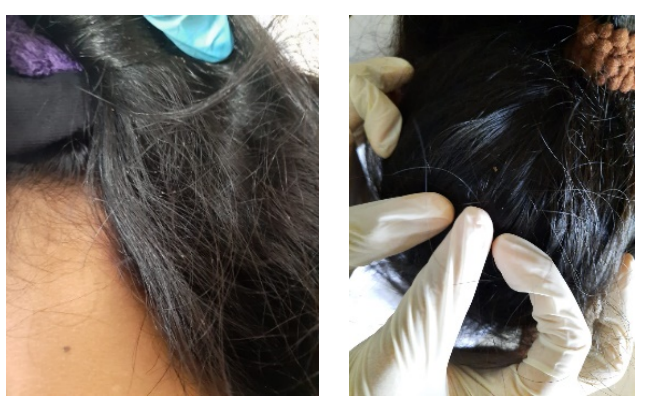

Gambar 1. Pemeriksaan Pediculus humanus capitis pada santri

Pediculus humanus capitis ini mempunyai siklus hidup dari telur, kemudian menjadi nimfa dengan tiga stadium, lalu menjadi kutu dewasa (CDC, 2019). Kutu kepala ini mengisap darah sedikit demi sedikit dan darah diisap dalam jangka yang waktu lama. Parasit ini lebih menyukai rambut di kepala bagian belakang dari pada rambut di kepala bagian depan karena daerah belakang kepala atau daerah occipital merupakan predileksi dari kutu kepala untuk meletakkan telurnya. Hal ini mungkin disebabkan oleh daerah occipital yang merupakan tempat lebih lembab dan lebih terlindungi dibanding daerah lain di bagian kepala. Apabila penyakit ini tidak diobati, hal tersebut dapat menimbulkan komplikasi berupa infeksi yang berat. Infeksi berupa rambut yang melekat satu dengan yang lain dan menyebabkan lekatan ini mengeras; telur kutu kepala atau disebut juga nits dan eksudat pus/ nanah yang timbul dari luka gigitan dari kutu yang kemudian meradang dan kadang dapat juga ditumbuhi jamur. Keadaan ini disebut dengan plica palonica, (Sungkar, 2008). Oleh karena itu, pengobatan terhadap pedikulosis kapitis ini sangat penting.

Pada santri yang terinfestasi dengan Pediculus humanus capitis ini diberikan terapi berupa lotion permethrin $1 \%$. Pemberian obat ini langsung diberikan kepada santri dengan terlebih dahulu menjelaskan cara pemakaiannya. Penjelasan tentang pemakaian obat ini didampingi oleh musyrif/ musyrifah dari santri tersebut. Selain pemberian obat kutu kepala pada santri, diberikan sisir serit atau sisir kutu (antilice), satu santri satu sisir serit.

Penatalaksanaan terhadap penyakit pedikulosis kapitis tidak bisa hanya dengan pemberian lotion permethrin saja, tetapi perlu pemberantasan secara mekanik, yaitu dengan menggunakan sisir serit. Penggunaan sisir serit dilakukan setelah anak mencuci rambut. Ketika rambut masih dalam keadaan basah, rambut disisir menggunakan sisir serit atau sisir kutu (antilice) yang disebut juga dengan sisir basah. Dengan demikian, akan banyak kutu kepala yang terjaring di sisir (Sungkar et al., 2019; Nutanson et al., 2008; Lye et al., 2017).

Berdasarkan penelitian pada santri di Pesantren Desa Pamijahan, Kabupaten Bogor tentang keefektifan pemberian lotion permethrin $1 \%$ dengan penggunaan sisir basah dalam terapi pedikulosis kapitis tidak didapatkan hubungan yang bermakna antara keduanya. Namun, kedua terapi ini diberikan lotion permethrin $1 \%$ dan sisir basah menggunakan sisir serit atau sisir kutu sama-sama bermakna dalam mengurangi atau menghilangkan pedikulosis kapitis (Sungkar et al., 2019).

Santri yang terinfestasi dengan kutu kepala ini juga diberikan penyuluhan tentang penyakit tersebut, seperti yang terlihat pada gambar 2 berikut. Penyuluhan yang dilakukan berupa penyuluhan perorangan kepada masing-masing santri yang terinfestasi kutu kepala. Santri diberikan penyuluhan berupa pengetahuan tentang 
penyakit pedikulosis kapitis; diberikan pendidikan tentang personal hygiene dan lingkungan sekitar, yaitu lingkungan tempat tinggal agar dapat terbebas dari infestasi kutu kepala ini.

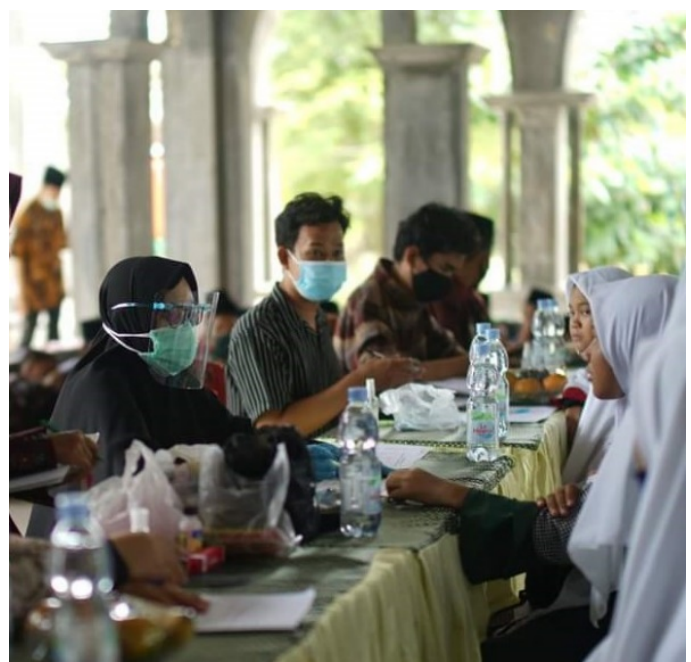

Gambar 2. Pemeriksaan dan penyuluhan pada santri

Hasil pemeriksaan santri di pesantren ini juga tidak berbeda dengan hasil pemeriksaan yang dilakukan pada tahun 2019, yaitu pada kelompok anak di panti asuhan Kecamatan Siak Hulu, Kabupaten Kampar yang didapatkan sebanyak 40,7\% anak menderita pedikulosis kapitis dan semua anak perempuan terinfestasi dengan kutu kepala ini (Maryanti et al., 2020). Penelitian Maryanti et al., tahun 2018 di tiga Panti Asuhan Pekanbaru juga didapatkan hasil yang tidak jauh berbeda, yaitu sebanyak 57,5\% anak dari 127 anak menderita pedikulosis kapitis (Maryanti et al., 2018). Hal ini menggambarkan bahwa infestasi pedikulosis kapitis pada anak selain di pesantren juga terjadi di tempat lain, seperti panti asuhan. Oleh karena itu, pentingnya perhatian khusus dalam pemberantasan penyakit parasit khususnya infestasi kutu kepala atau pedikulosis kapitis. Penyakit ini tidak bersifat fatal tetapi penyakit parasit ini dapat berdampak buruk pada santri, yaitu sulit untuk berkonsentrasi dalam belajar dan susah tidur karena rasa gatal di kepala dan dapat berakibat pada penurunan prestasi belajar dan perkembangan anak.

Pemberantasan penyakit pedikulosis kapitis ini perlu usaha dan motivasi yang tinggi dari santri-santri tersebut serta dari mentor/ musyrifah, guru/ ustazah, dan pimpinan pondok pesantren. Pada Pondok Pesantren Kecamatan Kandis ini sudah mempunyai poskestren (pos kesehatan pesantren) yang perlu diberdayakan sehingga dapat meningkatkan derajat kesehatan, khususnya santri. Hal ini memerlukan dukungan dari pihak pemerintah daerah, yaitu melalui pihak puskesmas di wilayah kerjanya untuk selalu memberikan penyuluhan atau edukasi tentang pentingnya menjaga kebersihan perorangan (personal hygiene) dan lingkungan tempat tinggal atau asrama sehingga terhindar dari penyakit menular, khususnya penyakit parasitik.

\section{Kesimpulan dan Saran}

Pengabdian kepada masyarakat berupa kegiatan pemeriksaan terhadap penyakit pedikulosis kapitis telah dilaksanakan dan angka kejadian infestasi Pediculus humanus capitis pada santri masih cukup tinggi, yaitu sebanyak 51,4\%. Semua yang terinfestasi kutu kepala ini adalah santri perempuan. Pemberian obat berupa lotion permethrin $1 \%$ dan sisir serit serta penyuluhan pada santri yang positif pedikulosis kapitis juga telah dilaksanakan. Kegiatan ini sebaiknya terus dilakukan dan berkesinambungan. Diperlukan juga kerjasama dengan pemerintah melalui puskesmas setempat dalam rangka mewujudkan pemberantasan penyakit pedikulosis kapitis di pesantren. 


\section{DAFTAR PUSTAKA}

Feldmeier, H., \& Heulkelbach J. (2009). Epidermal parasitic skin diseases: a neglected category pf povertyassociated plagues. Bull World Health Organ, 87, 152-9. DOI: 10.2471/BLT.07.047308.

Gharsan, F.N., Abdel-Hamed, N.F., Elhassan, S.A.A.M., \& Gubara, N.G.A.R. (2016) The prevalence of infection with head lice pediculus humanus capitis among elementary girl students in Albaha regionKingdom of Saudi Arabia. International Journal of Research in Dermatology. 2(1): 12-17. DOI: 10.18203/issn.2455-

4529.IntJResDermatol20161426

Kurniawan, E., Prihasti, W., \& Silalahi DK. (2019). Penyuluhan penggunaan listrik dari sumber energy surya di pesantren Al Muqarramah Kabupaten Bandung. Ethos:Jurnal Penelitian dan Pengabdian Kepada Masyarakat. 7(2): 355-61.

Lye, M.S., Tohit, N.F., \& Rampal, L. (2017). Prevalence and predictors of pediculosis capitis among primary school children in Hulu Langat, Selangor. Med J Malaysia. 72(1): 12-17.

Lukman, N., Armiyanti, Y., \& Agustina D.(2018). Hubungan faktor-faktor risiko pedikulosis capitis terhadap kejadiannya pada santri di pondok pesantren Miftahul Ulum Kabupaten Jember. Journal of Agromedicine and Medical Science; 4(2): 102-9.

Maryanti, E., Inayah, Ulfa, A., \& Wulandari S. (2018). Infestasi neflected parasites pada anak panti asuhan Kota Pekanbaru. Proceedings of Seminar Program Pengendalian Resistensi Antibiotik; 2018 Nov 28; Pekanbaru, Riau. Fakultas Kedokteran Universitas Riau. Hal. 57-61.
Maryanti, E., \& Lestari, E. (2020). Pendidikan kesehatan dalam rangka menuju panti asuhan bebas pedikulosis kapitis di Kecamatan Siak Hulu Kabupaten Kampar. Riau Journal Empowerment. 3(2): 97103.

Nasir, S., Ali, F., Muin, R. (2016). Rekayasa Peralatan ultrafiltrasi untuk penyediaan air siap minum bagi komunitas Pesantren Izzatuna dan Al Malul Khiar di Sumatera Selatan. Ethos: Jurnal Penelitian dan Pengabdian Kepada Masyarakat. 4(1): 105-110.

Natadisastra, D. (2009). Penyakit parasit pada dermatomuskuloskeletal. Dalam: Natadisastra D, Agoes R, editors. Parasitologi kedokteran: ditinjau dari organ tubuh yang diserang. Jakarta: EGC.295-6.

Nutanson, I., Steen, C.J., Schwartz, R.A., \& Janniger, C.K. (2008). Pediculus humanus capitis: an update. Acta Dermatovenerol Alp Pannonica Adriat. 17(4): 147-59. https://pubmed.ncbi.nlm.nih.gov/19 104739/

Menaldi, SLS., Bramono, K., Indriatmi W. (2015). Ilmu Penyakit kulit dan kelamin. Edisi ke-7. Jakarta: FKUI.

Sardjono, TW. (2008). Penyakit parasitik masih terabaikan. Diakses dari https://prasetya.ub.ac.id/profteguh-wahyu-sardjono-penyakitparasitik-masih-terabaikan/

Soedarto. (2011). Buku ajar Parasitologi Kedokteran. Jakarta: Sagung Seto.

Sungkar, S. (2008). Penyakit yang disebabkan Artropoda. Dalam Parasitologi Kedokteran. Sutanto I, Ismid IS, Sjrifudin PK, Sungkar S. Editor. Edisi ke4. Balai Penerbit FKUI Jakarta.

Sungkar, S., Dwinastiti, YA., \& Haswinzky, RA., Irmawati FP., Wardhana AW., \& Sudarmono, P. 
168 Esy Maryanti, et al.

(2019). Effectiveness of web combing compared with $1 \%$ permethrin lotion for the treatment of pediculosis capitis. International Journal of Applied Pharmaceutics. 11 (6). DOI: 10.22159/ijap.2019.v11s6.33570. 